\title{
Improving Undergraduates' Argumentative Group Essay Writing through Self-assessment
}

\author{
Yong Mei Fung (Corresponding Author) \\ Department of English, Faculty of Modern Languages and Communication, \\ Universiti Putra Malaysia, 43400 UPM, Serdang, Selangor, Malaysia \\ E-mail: yong@upm.edu.my \\ Hooi Chee Mei \\ Department of English, Faculty of Modern Languages and Communication, \\ Universiti Putra Malaysia, 43400 UPM, Serdang, Selangor, Malaysia \\ E-mail: hooiesther@yahoo.com
}

Doi:10.7575/aiac.alls.v.6n.5p.214

Received: $15 / 05 / 2015$

URL: http://dx.doi.org/10.7575/aiac.alls.v.6n.5p.214

Accepted: 07/08/2015

\begin{abstract}
When writing an argumentative essay, writers develop and evaluate arguments to embody, initiate, or simulate various kinds of interpersonal and textual interaction for reader consideration (Wu \& Allison, 2003). This is quite challenging for English as a second language (ESL) learners. To improve the quality of their writing, students need to review their draft throughout the writing process. This study aimed to investigate the effect of self-assessment in group writing and how group work improves students' writing ability. An intact class comprising 22 first-year undergraduates participated in the study. Data were collected from pre- and post-treatment writing tests, semi-structured interview and reflection entries. The results revealed that self-assessment has a significant effect on students' writing performance. Group work also enhanced social and cognitive development of the students. This study provides insights into the use of selfassessment in writing class to develop learner autonomy and improve writing ability.
\end{abstract}

Keywords: Argumentative essay, Self-assessment, Learner autonomy, Group writing, ESL learners

\section{Introduction}

Writing is a way of conveying opinions to other people. The ability to write effectively is a tedious process that demands a lot of effort that even many native speakers of English are unable to master the writing skill well (CelceMurcia, 2001). Writing is challenging for English as a second language (ESL) learner who does not have the skills to write coherent and cohesive text. In institutions of higher learning, students are required to have the necessary skills to write well-structured persuasive arguments (Butler \& Britt, 2011). The goal of argumentative writing is to convince an audience to take the writer's stand where conflict exists between the beliefs and attitudes of the writer and the reader (Hinkel, 2002).

Many ESL students face difficulties in writing because they are not proficient in the language. Cheng and Chen (2009) found that writers were unable to convey their ideas clearly because they were weak in sentence structures. One of the ways to help students overcome their writing problem is to get them to work in a small group. Students will feel less anxious and more confident when interacting with peers during pair or small group activities (Storch, 2005).

Group work is very common in higher education contexts because it promotes social interaction (Wigglesworth \& Storch, 2012). Group work is defined as students working together to complete a common goal (Hubert, 2010). The use of small group and pair work, particularly in second language (L2) classrooms, provides the weaker students with the appropriate level of assistance from more capable peers, which helps to stretch them beyond their current level towards their potential level of development (Storch, 2005).

Sociocultural theory which posits that all higher-level human development is socially mediated (Lantolf $\&$ Thorne, 2006) underpins this study. This theory stresses on the social interaction between people and the culture in which they live. Social interaction is prerequisite to cognitive development. It is closely linked with zone of proximal development (ZPD). ZPD occurs as a result of the internalisation of ideas in the sociocultural environment (Wenger, 1998). As students interact with others socially, they internalise and transform the help they receive and use it for subsequent independent learning. When internalisation takes place, the students are able to gain control over their own learning.

Some researchers have argued that self-assessment promotes learner autonomy in the writing class and future writing work (Bardine \& Fulton, 2008; Vickers \& Ene, 2006). Self-assessment serves to enrich students' learning over a long period of time (Hubert, 2010). It encourages the students to gain useful inputs about the level of their learning and how to improve it. Using self-assessment in group writing also means that students reflect on their role in the group and their 
learning process to provide self-improvement (Hubert, 2010). Students diagnose their own weaknesses and improve their writing performance as well as assess their own writing (Nimehchisalem et al., 2014). This practice promotes continuous assessment of students' writing to raise awareness of their different levels of abilities (Nielsen, 2012).

Literature on self-assessment reveals that studies mostly used observation and action research (Hubert, 2010; Lam, 2010; Nielsen, 2012). In Hubert's (2010) study on grade 6 students, she found that the students were able to reflect on both good and bad written work and their own development through self-assessment. Lam (2010)

found that through self-assessment EFL undergraduates' motivation and interest in writing increased, less proficient students' linguistics awareness was enhanced and writing strategies were monitored. Khodadady and Khodabakhshzade's experimental study (2012) revealed that portfolio and self-assessment have significant effects on self-regulation and writing ability of Iranian English major undergraduates. Nielsen (2012) proposes a theoretical framework for self-assessment methods in writing class as well as summary of common practices and strategies of selfassessment for effective classroom use. Nimehchisalem et al. (2014) developed a comprehensive self-assessment checklist to evaluate ESL undergraduates' argumentative essay. Nielsen (2012) states that to test the many theories of the effect of self-assessment on student writing outcomes, additional studies of self-assessment practices using experimental methods should be conducted in future research. This study is a response to the call for more investigation on self-assessment.

The objectives of this study are to examine the effect of self-assessment on writing performance and group work in developing students' writing ability. This study seeks to answer the following research questions:

1. What is the effect of self-assessment on students' writing performance?

2. How does group work improve students' writing ability?

\section{Methodology}

\subsection{Participants}

The participants of this study consisted of 22 first-year undergraduates who were enrolled in an expository writing course in a public university. There were 17 females and five males. Their age ranged from 20 to 21 years old. All of them were Malaysians except for one who was an international student. They were of intermediate level of language proficiency, Bands 3 and 4, based on the Malaysian University English Test (MUET). Bands 1 and 2 are low level language proficiency, while Bands 5 and 6 are advanced level language proficiency.

In the first half of the course, the students were taught the elements of paragraph and essay writing, as well as different types of essays; for instance, comparison and contrast, cause-effect and argumentative essays. In the second half, the students were required to write an argumentative essay which was part of their graded $20 \%$ assignment. The class met twice a week over one semester (14 weeks). The first meeting was a two-hour lesson and the second meeting was an hour lesson. The students were assigned to work in groups of three except for two groups who worked in pairs to write the argumentative essay. The grouping was done by the instructor cum researcher to ensure that the groups consisted of students of mixed ability.

\subsection{Data Collection Methods}

Quasi-experimental design was adopted in this study. It involved quantitative and qualitative data collection methods in an intact class. The quantitative data were collected from pre- and post-treatment argumentative essays which were done individually. The topics were different for both essays. In this study, the term pre- and post-treatments is used interchangeably with pre-and post-tests.

For the treatment, the whole class brainstormed and decided on one argumentative topic to write in their assigned group. Self-assessment checklist was distributed to evaluate their progress at the planning, drafting and revision stages. The checklist was adapted from Nimehchisalem et al. (2014) which was divided into three main sections, namely Before Writing (seven items), While Writing (seven items) and After Writing (nine items) (see Appendix A). It was used by the students in their groups to assess their essay by ticking the items they had fulfilled in the checklist and items which they missed out while drafting their argumentative essay. The checklist was colour-coded to differentiate the various stages of writing as they assessed their draft each week. The students took a week to plan, two weeks to draft and one week to revise their final draft.

Semi-structured interview was conducted to obtain the students' feedback on the use of the self-assessment checklist, group work and peer review feedback. The respondents were selected based on a voluntary basis. The interview was conducted individually with 12 students to enable them to express their views freely. The researcher has better control over the types of information received because she can probe to elicit more information (Creswell, 2014). Each interview took approximately 20 to 25 minutes.

The students were asked to write four reflection entries individually to record what they have learned from using the self-assessment checklist and writing in a group. The students wrote about the benefits of the self-assessment checklist in the first reflection. In the second reflection, the students were asked whether they liked working in a group and the reasons. For the third reflection, the students commented on what they learned from their group members. In the final reflection, they reflected on how they have improved in their writing. 
In week 2, the instructor explained about the research to the class to obtain their consent. A pre-treatment writing task was administered in the same week. The title of the argumentative essay was "Facebook is a platform for establishing relationships. Take a position on this statement." The students were given one hour to complete the task.

The treatment period commenced in week 8. The students worked in groups to brainstorm and plan the outline for the argumentative essay entitled "College education is not enough for finding a well-paid job. Take a position on this statement." In the second meeting of week 8, they assessed their outline using the checklist for Before Writing stage. Then they made the appropriate changes based on what was lacking.

In week 9, they wrote their first draft in the first meeting of the 2-hour class. In the second meeting, they used a fresh checklist to assess the While Writing stage. In the self-assessment checklist, they would tick against the items that they had fulfilled and those which were pending. They made the appropriate changes and modification to the draft by referring to the checklist criteria. The first reflection on the self-assessment checklist was given to the students to write at their leisure.

In week 10, during the first class meeting, the students exchanged their second draft with peers from the other groups. The students were required to comment and to give suggestions to improve their draft. They used a peer review worksheet and occasionally referred to the self-assessment checklist as a guide. This exercise allowed the students to provide immediate feedback. After getting the feedback, the groups read through the comments thoroughly and revised their second draft. They continued their revision in the second meeting and used a new unmarked self-assessment checklist to assess the third draft for While Writing stage. At the end of the week, they submitted their third draft to the instructor for teacher feedback. The second reflection on group work was assigned.

At the beginning of week 11, the instructor handed back the students' drafts with her comments for them to work on their final draft. The students used a different colour-coded checklist for final checking in After Writing stage to edit and proofread their draft. The third reflection about what they learned from their group members was assigned.

In week 12, the students submitted the final product. The last reflection was given to them to reflect on how they have improved in their writing. The post-treatment essay entitled "Online dating is a basis for relationships. Take a position on this." was assigned in week 13. The semi-structured interview was conducted in week 14.

\subsection{Data Analysis}

The students' pre- and post-treatment essays were evaluated using Jacobs, Zingraf, Wormuth, Hartfiel, and Hughey's ESL Composition Profile (1981) which consists of five dimensions. These dimensions helped the instructor to grade the students' argumentative essays on content, organisation, vocabulary, language use, and mechanics. The quantitative data were analysed using Statistical Package for Social Sciences (SPSS) version 21. Paired sample t-test was used to test the significance of difference between the students' pre-treatment essay and post-treatment essay scores. The significance level was set at .05 for both essays.

Qualitative data from students' reflection entries and semi-structured interview responses were categorised into common themes.

\section{Results and Discussion}

\subsection{Quantitative Data from Pre- and Post-tests}

To answer the first research question, the students' argumentative pre-treatment essay scores were compared with the post- treatment scores (see Table 1). The results show that the students improved in their writing because there is quite a huge mean difference between the pre-test scores (70.86) and post-test scores (75.05) which is 4.18.

Table 1. Descriptive statistics for pre- and post-test scores

\begin{tabular}{llllll}
\hline & & Mean (upon 100) & $\mathrm{N}$ & Std. Deviation & Std. Error Mean \\
\hline \multirow{2}{*}{ Pair 1 } & Overall Marks for Pre-test & 70.8636 & 22 & 9.78967 & 2.08716 \\
& Overall Marks for Post-test & 75.0455 & 22 & 7.36450 & 1.57012 \\
\hline
\end{tabular}

From Table 1, the result of the within group comparison indicates that the students' post-test $(M=75.05, S D=7.36)$ is considerably higher than their pre-test $(M=70.86, S D=9.79)$. The significance of the mean difference between the students' scores in the pre-treatment essay and post-treatment essay was run (see Table 2).

Table 2. Paired samples t-test results

\begin{tabular}{llllll}
\hline & Mean & $\mathrm{t}$ & $\mathrm{df}$ & Sig. (2-tailed) \\
\hline \multirow{2}{*}{ Pair 1 } & Overall Marks for Pre-test & -4.18182 & -4.348 & 21 & .000 \\
& Overall Marks for Post-test & & & & \\
\hline
\end{tabular}

* Correlation is significant at the .05 level (2-tailed) 
Table 2 shows that the mean difference of 4.18 between the pre-test and post-test scores is statistically significant, (21) $=4.35, p=.00$. Thus, the result proves that the self-assessment improved the students' writing performance. This finding is similar to Khodadady and Khodabakhshzade's study (2012) which revealed that portfolio and self-assessment not only make learners autonomous in writing, but also improved their writing ability.

Analysis of the five dimensions (content, organisation, vocabulary, language use, and mechanics) was carried out to investigate whether self-assessment has significant effects on the students' argumentative essays. Table 3 shows that the students' pre-test scores for each dimension are significantly lower than their post-test scores.

Table 3. Descriptive statistics for pre- and post-test scores $(n=22)$

\begin{tabular}{llll}
\hline Dimensions & & Mean & Std. Deviation \\
\hline Pair 1 & Content for Pre-test & 19.6364 & 2.76966 \\
& Content for Post-test & 20.4545 & 2.82383 \\
\multirow{2}{*}{ Pair 2 } & Organisation for Pre-test & 15.0909 & 2.50541 \\
& Organisation for Post-test & 16.1364 & 1.75378 \\
Pair 3 & Vocabulary for Pre-test & 15.0909 & 1.99783 \\
& Vocabulary for Post-test & 16.0455 & 1.73143 \\
Pair 4 & Language for Pre-test & 16.3182 & 2.76692 \\
& Language for Post-test & 17.4091 & 2.48153 \\
Pair 5 & Mechanics for Pre-test & 4.7273 & .70250 \\
& Mechanics for Post-test & 5.0000 & .00000 \\
\hline
\end{tabular}

The mean difference between the pre-test and post-test scores for each dimension were tested for their statistical significance using paired samples t-test. Table 4 summarises the SPSS output for these tests.

Table 4. Paired samples t-test results

\begin{tabular}{|c|c|c|c|c|c|}
\hline & & Mean & $\mathrm{t}$ & df & Sig. (2-tailed) \\
\hline \multirow{2}{*}{ Pair 1} & Content for Pre-test & -.81818 & -1.765 & 21 & .092 \\
\hline & Content for Post-test & & & & \\
\hline Pair 2 & $\begin{array}{l}\text { Organisation for Pre-test } \\
\text { Organisation for Post-test }\end{array}$ & -1.04545 & -4.176 & 21 & .000 \\
\hline Pair 3 & $\begin{array}{l}\text { Vocabulary for Pre-test } \\
\text { Vocabulary for Post-test }\end{array}$ & -.95455 & -3.470 & 21 & .002 \\
\hline Pair 4 & $\begin{array}{l}\text { Language for Pre-test } \\
\text { Language for Post-test }\end{array}$ & -1.09091 & -5.267 & 21 & .000 \\
\hline Pair 5 & $\begin{array}{l}\text { Mechanics for Pre-test } \\
\text { Mechanics for Post-test }\end{array}$ & -.27273 & -1.821 & 21 & .083 \\
\hline
\end{tabular}

* Correlation is significant at the .05 level (2-tailed)

The results show that not all the mean differences between the pre-test and post-test scores for each dimension are statistically significant. There is no significant effect of self-assessment on content and mechanic scores, but there is significant effect of self-assessment on organisation, vocabulary, and language use scores. This is because the differences between the pre-test and post-test scores for organisation $[\mathrm{t}(21)=-4.18, p=.000]$, vocabulary $[\mathrm{t}(21)=-$ $.3 .47, p=.002]$, and language use $[\mathrm{t}(21)=-5.27, p=.000]$ are statistically significant since the significant value, $p$ is less than .05 , This means that organisation, vocabulary and language use of the students' argumentative essays are positively affected by self-assessment.

However, the differences between the pre-test and post-test scores for content $[\mathrm{t}(21)=-1.77, p=.092]$ and mechanics $[\mathrm{t}(21)=-1.82, p=.083]$ are not statistically significant since $p$ is more than .05 . This could be attributed to the posttreatment essay topic, which was not very familiar to the students, who had no experience in online dating. Thus, they were unable to justify their arguments or express their ideas well in their writing. On the other hand, the students had no problem with mechanics in the pre-test because most of them scored 4 out of the total 5 marks. All of them scored full marks of 5 for mechanics in the post-test. Therefore, there is not much difference between the pre and post-test mechanic scores. The effect size of this study is shown in Table 5. 
Table 5. Effect size (Tests of between-subjects effects)

Dependent Variable: Overall Marks for Post-test

\begin{tabular}{lllllll}
\hline Source & $\begin{array}{l}\text { Type III Sum of } \\
\text { Squares }\end{array}$ & df & Mean Square & F & Sig. & $\begin{array}{l}\text { Partial Eta } \\
\text { Squared }\end{array}$ \\
\hline Corrected Model & $.000^{\mathrm{a}}$ & 0 &. &. &. & .000 \\
Intercept & 123900.045 & 1 & 123900.045 & 2284.464 & .000 & .991 \\
Error & 1138.955 & 21 & 54.236 & & & \\
Total & 125039.000 & 22 & & & & \\
Corrected Total & 1138.955 & 21 & & & & \\
\hline
\end{tabular}

a. R Squared $=.000$ (Adjusted R .' Squared $=.000)$

From Table 5, effect size is determined from partial Eta squared. This means that the effect size is very large as the partial Eta squared is .991 (Cohen, 1988). It shows that $99.1 \%$ of the change in the overall marks for post-test is caused by self-assessment in group writing.

\subsection{Qualitative Data from Students' Reflections and Interview Responses}

Qualitative data from students' reflections and interview responses were collected to answer the second research question. Excerpts from the interview responses were transcribed verbatim. The names of the students were pseudonyms. Data were organised according to common themes.

\subsubsection{Benefits of Group Writing}

Data from the students' reflections and interview responses revealed that all of them liked to write in a group. However, one student stated that he has both preferences for writing in a group and individually. He also stated that there are many assignments that require a lot of writing and reading, thus, working individually is more demanding. As Adrian mentioned:

Should the assignments be hard for a single student to do, I would say that I prefer to write in a group. A lack of interest towards certain topics also causes me to look for a group to work with.

Most of the time, Adrian prefers to write alone because it can help him to get the work done quickly. According to him, writing alone enabled him to express what he wanted to say without many obstructions.

Nur listed the advantages and disadvantages of working in a group. She wrote in her reflection entry that she was able to share her opinions with her group members and this encouraged her group to choose the best idea for their essay. She also stated that writing in a group reduced the workload as her group divided the tasks. However, working in a group could lead to arguments and dissatisfaction if group members had differing views. Nevertheless, if they have cooperative members in the group, it is possible to write a good essay as the end product.

In his reflection entry, Wai Kin mentioned that writing in a group could generate good questions. When members discussed the topic, they generated many questions for discussion. According to him,

When I discuss about a topic with my friends in group, I can freely ask any question which I have in my mind about any point in the topic and I will get the answer. Similarly, they ask questions.

Haryati, who is less proficient than her group members, concurred with Wai Kin's view. In the interview, she explained that each member would generate different ideas that did not cross her mind. It stimulated her group to think more critically because they had to negotiate and decide which ideas were suitable to be included in the draft. In the process of negotiation, they were actively involved in the construction of new knowledge. She said:

I never thought that completing an essay in a group was way much better than when I do it on my own. We also argue on our ideas, because each of us want to prove that our idea is the best and the most suitable to be used. Besides, we share our thought on this topic which means we are indirectly engaging with the topic given.

Azariah stated that she learned about her group members' culture through group discussions. In her reflection, she wrote that her group members were very tolerant with her as they tried to understand what she wanted to convey although at times there were some misunderstandings. Being a foreign student, she also indicated that she tried to understand cultural differences; hence, learning to accept these differences opened her to a whole new and exciting experience when learning to write in a group. According to her,

My group members are very patient with me when they do not understand the things I want to state until there are some confusions.

I learn to accept cultural differences and it makes me excited to work in a group while writing. 
Rahman loved doing the assignment with his group members because the work could be completed faster than writing alone. His group also divided their task equally. From his group members, he learned to see things from different perspectives, to be responsible and disciplined. In his reflection, he mentioned:

All of us have different own point of view on a topic. I love writing in group because I managed to learn on my group members ethics in doing a task.

Ili felt that by working in group, she could avoid confusion that arises by referring to her group members. She also needed to have a positive attitude and be open for criticism in order to improve herself. In the interview, she mentioned:

If I do not know anything, I will refer to someone, who knows more than me.

I should not be snobbish, but be humble and open-minded for every comments received in order to improve myself to be better than before.

Sharon, who is a more proficient student, pointed out that after writing in a group she became more aware of the mistakes that she made in the past particularly grammatical mistakes. She explained that her writing has become more comprehensible and relevant to the topic. She also mentioned that her writing is more varied because the group discussion has diversified her thinking. In the interview, Sharon pointed out:

I have certainly improved my critical thinking skills when it comes to creating sentences in my writing and arranging the words for a smooth flow in my writing.

My writing has become more diverse in terms of points as my experience in writing in a group has opened up my mind to various opinions from different people.

She also stated in her reflection that she had good group members as they contributed a lot during the discussion. Coconstruction of knowledge and cognitive development occurred during the discussion because she learned from her group members regarding the style of writing and relevant information related to the topic. She wrote:

My group members made me realise that I should not be complicated in my writing. I should just write in a clear manner.

My group members shocked me by giving us related examples to our essay that we never thought of. This is really great as we are able to look at it in a different angle.

Nurul also agreed with Sharon about contribution from group members. Nurul mentioned that although her group faced a lot of difficulties during the writing process, she realised that she has gained a lot of new knowledge from them at the end. She wrote in her reflection:

I have always loved writing, but at times I tend to lose motivation, as well. My group members always motivate me to write and I learn a lot of new things from them.

In the interview, Nurul responded that she has learned to think from a wider perspective by working in a group. Now, she is able to generate better ideas. This has increased her interest and motivation to write more. She said:

To be frank, I have started to write more than I have had in the past, even not for study purpose.

\subsubsection{Functions of Self-assessment in Group Writing}

All the students except one person agreed that self-assessment was beneficial to them when they wrote the argumentative essay in groups. In terms of planning the outline, Aida mentioned that self-assessment prepared her to write in different stages, such as before writing, while writing, and after writing. In her reflection entry, she wrote:

It makes the writing become appropriate. Writing starts with brainstorms the idea based on the topic and arranges it accordingly during before writing, while writing, and after writing.

Sharon agreed with Aida. She explained that she could compose the draft better after brainstorming their ideas thoroughly during the planning stage. She also saw improvement in her writing through self-assessment. She wrote in her reflection entry:

For the planning of my essay, at first it was hard for me to understand, after your instructions on how to use the checklist, now, I can do it step-by-step correctly. I see myself improving in my writing using the checklist.

Sharon also indicated that self-assessment created awareness of what was missing or lacking in her group's writing. She generated ideas for arguments and counter-arguments, claims, as well as refutation. In the interview, she said: 
Self-assessment checklist can notify me on what is the insufficiency of my writing such as lack of evidence in a paragraph to give a strong and concrete argument based on my opinion in an argumentative essay.

In her reflection entry, Bella stated the items in the self-assessment checklist helped her group to assess if they had provided adequate and sufficient examples for the topic. This also ensured that she had not missed out important features in her writing.

Self-assessment guided me to know which examples and evidence to put in my writing as it has a column for me to check whether I have done the things that I needed to write in the essay.

Mariah mentioned that through self-assessment checklist, she was aware that she needed to acknowledge sources when she wrote the group essay. She avoided plagiarism because she knew that it was unethical and unacceptable practice at the university. In her reflection, she stated:

I will make sure that my points are not plagiarizing other people's works. As we all are aware, plagiarizing is a wrong action and can get you penalized.

Sharon did not know that she needed to acknowledge the authors when she cited people's work. Through her group members, she learned how to cite using American Psychological Association (APA) style. In the interview, she mentioned:

Normally, I will not acknowledge sources although I refer to works from different people. I did not know the importance of it. I learn all of these citations especially APA from my group members.

According to Adrian, self-assessment assisted his group to ensure that there was coherence and cohesion in their writing. This made their draft more comprehensible. He also explained that before checking the draft using the checklist, he did not know that he needed to use transitions markers. After using the checklist, he realised the importance of transitions to provide a better flow for the readers. He mentioned in the interview:

This is very significant as it will make the essay more reader-friendly.

Without the correct usage of transitions, I believe certain readers will get lost while reading an essay. Therefore, I strongly believe that the checklist did guide our writing process.

Mariah agreed with Adrian's view. In her interview response, she mentioned that self-assessment was very useful in the writing process. It aided her group in producing an essay that flowed smoothly. She said:

Without any doubt, it had made our writing process move smoothly.

Adrian also stated that self-assessment heightened the awareness of their grammatical mistakes. By going through the checklist, they were able to detect the mistakes they made in their writing. In the interview, he stated:

There were times when my group and I did not realise the mistakes in our writing. After using the checklist, the mistakes were identified.

Self-assessment also served as a practice for students to gauge their strengths and weaknesses as writers and to allow room for growth. Arvin mentioned in the interview that self-assessment was useful because it improved their group's editing and proofreading skills. It also guided their writing process; therefore, he felt that their group writing was successful.

It allows us to review our strengths and weaknesses as a writer to see how we can continue to grow.

Without the checklist, I do not think we are able to produce a better essay. It is a guide for us to know what we should have in the essay and it also reminds us to proofread our essay every now and then, thus the group project is successful.

As self-assessment was used in group writing for before writing, while writing and after writing stages to scrutinise their written work, it guided his group to stay on track. In his reflection, Arvin mentioned:

It record moments of uncertainty.... therefore, having self-assessment checklist helps us to get on track where we stopped. 
Self-assessment was useful for the students to plan their outline and provide evidence to justify their arguments. It also created awareness of what was missing or lacking and acknowledging sources in their writing. Students were also conscious of coherence and cohesion, as well as grammatical mistakes.

\subsubsection{Importance of Peer Review Feedback}

All of the students except for one claimed that peer review feedback was helpful for group writing. Peer review feedback was important for the students to check whether their introduction was attention-grabbing with a proper thesis statement. According to Sharon, the feedback made her group realise that their writing needed to be reader-friendly. In the interview, she stated:

We did not know how to make the introduction interesting or how to improve our writing to cater for the readers to understand the content. Through peer review feedback, it helped to make our writing more proper.

Adrian explained that his group members were unaware that they did not provide adequate examples in their draft; the feedback was useful for them to construct a more comprehensive essay. They also clarified with the group who provided the feedback for confirmation.

We lack statistics and numbers. Because of their feedback, we tried to improve our essays. The feedback was easy to respond to. I will go back to the group to double check.

Wai Kin stated that the feedback provided useful tips. He explained that after his group completed their outline, they were fully satisfied with it. They thought that their draft was good, but the peer review feedback highlighted mistakes which were undetected. Based on the comments, the group reorganised their ideas and revised the draft thoroughly to improve their writing. In his reflection, he wrote:

We thought it was good enough, but apparently it was not. We could not see it before, but when our peers checked it for us, we started to see every mistake that we made and some that were very subtle too. So starting from there, we changed basically $80 \%$ of the whole outline and improvised everything.

Ili also agreed with Wai Kin. According to her, the peer review feedback was useful because her group needed others' views about their writing. She would also refer to her group members, who are more proficient, if she did not understand the comments. From the feedback, they realised about their grammatical errors which might affect the quality of their work. Besides that, their peers also highlighted the lack of unity and coherence in their draft. From the interview, she stated:

We cannot only have our own opinions. I will ask my group members if I do not understand the comments. We made little mistakes like grammatical errors, which may affect our essays. We did not realise there were irrelevant points in our essay until we read the comments given through peer review feedback.

Although peer review feedback assisted the students to correct mistakes in their drafts, the instructor's role was still deemed important. To avoid confusion, Rahman's group had to clarify with the instructor about the peer feedback comments He mentioned in the interview:

We thought our work is perfect, but then we saw there were mistakes. There are clear suggestions, but not entirely correct. The feedback was a bit confusing, but it did help because we asked you to further confirm.

Haryati's group received feedback that their thesis statement was not detailed enough because they did not include the counter-argument. They were confused about the comment as they felt that they had constructed a clear thesis statement. The group counter-checked their writing with the instructor to ensure that they were on the right track. In her reflection, she stated:

The feedback stated that we needed to write our counter-argument. We were very sure that we did our thesis statement correctly, but still we asked you to confirm whether we are on the right side or not. Luckily, we are on the right side.

Mariah felt that instructor's feedback was much better for her group because the peer review feedback did not specify relevant examples and suggestions for improvement. She considered the instructor as the expert in providing accurate feedback. In the interview, she mentioned: 
They did not really comment on our essays. When we received the comments, we were confused because we did not understand what they meant. We did not really pay much attention to their feedback, but depend on your feedback more.

From the peer review feedback, the students learned to improve their writing by taking into account the responses of actual and anticipated readers. Although it was beneficial for most of the students, some suggestions and examples given were not clear enough. Therefore, the students had to refer to the instructor for confirmation.

The findings of this study are consistent with Hubert's (2010) findings, whereby students like collaborative learning, prefer having specific roles and learn better when the group functions cohesively. It also concurs with Lam's (2010) study which shows that students' linguistic awareness is heightened when they revise their work and self-assessment serves as a tool for monitoring strategies used during the writing process.

\section{Conclusion}

Students' writing performance improved as a result of self-assessment and group work. Their post-treatment essays show maturity in thinking, wider range of vocabulary, proper language use and better organisation. Consistent assessment of their work has heightened their awareness and consciousness of mistakes made. By engaging in group discussion, they have the opportunity to look at things from different perspectives with their members who are from different cultural backgrounds and level of proficiencies. Some of the weaker students demonstrated increased cognitive development while better students gained from the deliberation of ideas. Through group work, the students also have developed social skills when they are opened to criticism, learn to negotiate and be independent of the instructor. These skills are vital in developing learner autonomy.

Students have become competent to respond to the comments received from peer review feedback to construct a more reader-friendly essay. On the other hand, when the students evaluate their peer's draft, their thinking becomes more critical and analytical. They also avoided the mistakes made by their peers. Therefore, self-assessment as well as giving and receiving feedback should be integrated as part of the writing process. Nonetheless, the role of the teacher as a facilitator is necessary when students do not have the experience to assess their work accurately and proficiency to provide good feedback.

Based on the findings of the study, a few recommendations are suggested for future studies. A longer duration of time and a larger sample of students will yield more in-depth findings. Self-assessment should be used in individual essay writing, so that students are able to assess their writing process individually and gauge how they fare throughout the various stages. Topics of essays should be carefully chosen and familiar to students' experiences, so that the students are able to relate to it. The self-assessment used in this study is suited for argumentative essay. Future researchers could develop a similar comprehensive self-assessment checklist for other types of essays.

\section{References}

Bardine, F., \& Fulton, P. (2008). Analyzing the benefits of revision memos during the writing and revision process. The Clearing House, 81(4), 149-54.

Butler, J. A., \& Britt, M. A. (2011). Investigating instruction for improving revision of argumentative essays. Written Communication, 28(1), 70-96.

Celce-Murcia, M. (2001). Teaching English as a second or foreign language (3th ed.). Boston: Heinle \& Heinle.

Cheng, F., \& Chen, Y. (2009). Taiwanese argumentation skills: Contrastive rhetoric perspective. Taiwan International ESP Journal, 1(1), 23-50.

Cohen, J. (1988). Statistical power analysis for the behavioral sciences (2nd ed.). Hillsdale, NJ: Erlbaum.

Creswell, J. W. (2014). Research design: Qualitative, quantitative, and mixed methods approaches (4th ed.). Thousand Oaks: Sage.

Hinkel, E. (2002). Second language writers' text. Mahwah, NJ: Erlbaum.

Hubert, J. (2010). Collaborative learning and self-assessment through reflective writing. The International Journal of Learning, 17(5), 385-398.

Jacobs, H., Zingraf, S., Wormuth, D., Hartfiel, V. F., \& Hughey, J. (1981). Testing ESL composition: A practical approach. Rowley, MA: Newbury House Publishers.

Khodadady, E., \& Khodabakhshzade, H. (2012). The effect of portfolio and self-assessment on writing ability and autonomy. Journal of Language Teaching and Research, 3(3), 518-524.

Lam, R. (2010). The role of self-assessment in students' writing portfolios: A classroom investigation. TESL Reporter, 43(2), 16-34.

Lantolf, J.P., \& Thorne, S.L. (2006). Sociocultural theory and the genesis of second language development.

Oxford: Oxford University Press. 
Nielsen, K. (2012). Self-assessment methods in writing instruction: a conceptual framework, successful practices and essential strategies. Journal of Research in Reading, 1-16.

Nimehchisalem, V., Yoong, D. S. C., Kaur, S. J. S., Siti Zaidah, Z., Norouzi, S., \& Sheren, K. (2014). A self-assessment checklist for undergraduate students' argumentative writing. Advances in Language and Literary Studies, 5(1), 22034714.

Storch, N. (2005). Collaborative writing: Product, process and students' reflections. Journal of Second Language Writing, 14, 153-173.

Vickers, C., \& Ene, E. (2006). Grammatical accuracy and learner autonomy in advanced writing. English Language Teaching Journal, 60(2), 109-116.

Wenger, E. (1998). Communities of practice: Learning, meaning and identity. Cambridge: Cambridge University Press.

Wigglesworth, G., \& Storch, N. (2012). What role for collaboration in writing and writing feedback. Journal of Second Language Writing, 21, 364-374.

\section{Appendix A}

Self-assessment Checklist for English as a Second Language Argumentative Writing

Based on the theories of language learning and teaching, this checklist has been developed to help you in writing argumentative papers. The checklist items have been divided into three sections, before writing, while writing, and after writing. In front of the items that you have followed or will consider, check the cell under 'Done' or 'Pending', respectively. You may decide to ignore some of the items depending on the task by checking the cell under 'Not applicable'.

Before Writing

\begin{tabular}{|ll|l|l|l|}
\hline Item & Done & Pending & $\begin{array}{l}\text { Not } \\
\text { applicable }\end{array}$ \\
\hline 1 & Review related texts. & & & \\
\hline 2 & $\begin{array}{l}\text { List a few arguments related to the topic. } \\
\text { Keep only the strong arguments that you can write to } \\
\text { support. }\end{array}$ & & & \\
\hline 3 & List a few counter-arguments. & & & \\
\hline 4 & Keep only the counter-arguments that you can refute. & & & \\
\hline 5 & $\begin{array}{l}\text { Consider how different people from different } \\
\text { backgrounds would argue for or against this topic. }\end{array}$ & & & \\
\hline 6 & $\begin{array}{l}\text { Based on these items, plan the content of your } \\
\text { paragraphs. }\end{array}$ & & & \\
\hline 7 &
\end{tabular}

While Writing

\begin{tabular}{|c|c|c|c|c|}
\hline \multicolumn{2}{|l|}{ Item } & Done & Pending & Not \\
\hline 1 & $\begin{array}{l}\text { Draft the body paragraphs first. You do not have to } \\
\text { start with the introduction. }\end{array}$ & & & \\
\hline 2 & Write following your plan. & & & \\
\hline 3 & $\begin{array}{l}\text { Avoid plagiarism. Acknowledging the source if } \\
\text { you are quoting. }\end{array}$ & & & \\
\hline 4 & Every idea should be related to the topic. & & & \\
\hline 5 & Present the content effectively. & & & \\
\hline 5.1 & Make a claim to your argument. & & & \\
\hline 5.2 & Provide strong evidence to support every claim. & & & \\
\hline 5.3 & $\begin{array}{l}\text { Elaborate on the link between your claim and } \\
\text { evidence if you anticipate it may not be clear for } \\
\text { your reader. }\end{array}$ & & & \\
\hline 5.4 & $\begin{array}{l}\text { Back up the link between the claim and evidence if } \\
\text { you anticipate it may be questioned by the reader. }\end{array}$ & & & \\
\hline 5.5 & $\begin{array}{l}\text { Anticipate rebuttals and provide proof for rejecting } \\
\text { them. }\end{array}$ & & & \\
\hline 5.6 & $\begin{array}{l}\text { Use qualifiers (e.g., certainly) to show the strength } \\
\text { of arguments. }\end{array}$ & & & \\
\hline 6 & Organize your ideas. & & & \\
\hline 6.1 & Present your arguments in the body paragraphs. & & & \\
\hline 6.2 & $\begin{array}{l}\text { Present your counter-arguments in the body } \\
\text { paragraphs. }\end{array}$ & & & \\
\hline
\end{tabular}


6.3 At the beginning of the first paragraph, write a general statement about the topic.

6.4 In the first paragraph, clearly state your stand in the argument. Alternatively, you may state your purpose of writing this paper.

6.5 At the end of the first paragraph, you may briefly list the arguments and counter-arguments to be discussed in the paper.

6.6 Present a summary of your arguments and conclude.

6.7 Link your sentences together.

6.8 Link your ideas together logically.

$7 \quad$ Revise the first draft of your paper to improve its content and organization.

After Writing

\begin{tabular}{|c|c|c|c|c|}
\hline Item & & Done & Pending & \\
\hline 1 & Fulfill the task. & & & \\
\hline 1.1 & Consider the word limit. & & & \\
\hline 1.2 & Remove the irrelevant ideas. & & & \\
\hline 1.3 & Respond to all parts of the task. & & & \\
\hline 2 & Present the content effectively. & & & \\
\hline 3 & Check the organization of your paper. & & & \\
\hline 4 & Check your use of vocabulary. & & & \\
\hline 4.1 & $\begin{array}{l}\text { Using technical words is good but you should } \\
\text { avoid using words that you do not know how to } \\
\text { use. }\end{array}$ & & & \\
\hline 4.2 & Avoid repetition by using synonyms and antonyms. & & & \\
\hline 4.3 & Avoid incorrect forms. & & & \\
\hline 4.4 & Use the correct word choices. & & & \\
\hline 4.5 & $\begin{array}{l}\text { It is good to use idioms, but some readers do not } \\
\text { like clichés. }\end{array}$ & & & \\
\hline 5 & Check your style. & & & \\
\hline 5.1 & Keep your style formal. & & & \\
\hline 5.2 & Make your style engaging. & & & \\
\hline 6 & Check your grammar. & & & \\
\hline 6.1 & Use verbs correctly. & & & \\
\hline 6.2 & Avoid fragments. & & & \\
\hline 6.3 & Use nouns correctly. & & & \\
\hline 6.4 & Use adjectives and adverbs correctly. & & & \\
\hline 6.5 & Use articles correctly. & & & \\
\hline 6.6 & Use prepositions correctly. & & & \\
\hline 6.7 & Avoid faulty comparisons. & & & \\
\hline 6.8 & Take case of parallel structures. & & & \\
\hline 6.9 & Use complex structures correctly. & & & \\
\hline 7 & Focus on mechanics. & & & \\
\hline 7.1 & Check your spelling. & & & \\
\hline 7.2 & Capitalize words like names. & & & \\
\hline 7.3 & Use punctuation marks correctly. & & & \\
\hline 8 & $\begin{array}{l}\text { Request a peer to review your final draft and give } \\
\text { you feedback. }\end{array}$ & & & \\
\hline 9 & Proofread the paper considering items 1-7. & & & \\
\hline
\end{tabular}

